\title{
LJUDSKI KAPITAL - OBRAZOVANJE - SOCIJALNA MOBILNOST IZVAN DOMOVINE NA PRIMJERU BOSANSKOHERCEGOVAČKIH MIGRANATA I NJIHOVIH POTOMAKA U AUSTRIJI
}

\section{- Sažetak -}

U radu se razmatra opći kontekst obrazovanja djece iz migrantskih porodica u drugačijem školskom sistemu i socijalnom okruženju u odnosu na zemlju porijekla njihovih roditelja, a potom se analizira obrazovna struktura bosanskohercegovačkih migranata u Austriji. Zbog postojanja migracijskog toka s dugom tradicijom između Bosne i Hercegovine (BiH) i Austrije, ova odredišna zemlja zauzima posebno mjesto na mapi bh. iseljeništva. Imajući $u$ vidu posljedicu vanjskih migracija, a to je direktni gubitak (pro)kreativnog potencijala, iseljavanje stanovništva u radno sposobnoj dobi ujedno predstavlja i odljev ljudskog kapitala (stečeno znanje, vještine i sposobnosti). Analiza pokazuje da obrazovna struktura migranata iz BiH u velikoj mjeri odražava obrasce i motive useljavanja u Austriju (radne migracije, izbjeglištvo, studiranje, spajanje porodica itd.), kao $i$ njihovo socijalno porijeklo. Porodična i dobna struktura bh. migranata nalažu da se obrati pažnja i na aktuelnu distribuciju njihovih potomaka prema vrstama srednjih škola. To je pitanje od posebnog interesa jer je obrazovanje, uz tržište rada, glavno područje strukturne integracije u useljeničko društvo, kao što je $i$ austrijsko.

Ključne riječi: ljudski kapital, obrazovna struktura, socijalna mobilnost, useljeničko društvo, bh. migranti, Austrija.

\footnotetext{
* Dr. sc. Mirza Emirhafizović, Fakultet političkih nauka Univerziteta u Sarajevu, Odsjek za sociologiju.

E-mail:emirhafizovicm@fpn.unsa.ba.
} 


\section{Uvod}

Bosna i Hercegovina, kao tradicionalno iseljenička zemlja, već decenijama unazad bilježi trend odljeva svog ljudskog kapitala u druge zemlje ${ }^{1}$. Austrija je posebno interesantna, ne samo kao zemlja prijema velikog broja izbjeglica već i kao jedna od najpoželjnijih destinacija za studente i radnu snagu iz BiH. Specifičnost bh. migranata, $u$ odnosu na druge doseljeničke grupe, ogleda se $u$ tome da je znatan procenat njih u Austriji došao kao de facto izbjeglice 1990ih godina, što implicira posve drugačiji migracijski obrazac od uobičajenih ekonomskih motiva iseljenja. Val je izbjeglica, od kojih su mnogi ostali živjeti u Austriji ${ }^{2}$, umnogome doprinio poboljšanju, inače loše, obrazovne strukture bh. migranata. Dotadašnju obrazovnu strukturu karakterizirao je izrazito visok udio osoba (uglavnom nekadašnjih tzv. gostujućih radnika) s potpunom ili nepotpunom osnovnom školom. S druge strane, obrazovanje potomaka prve generacija migranata odvija se u specifičnim društvenim okolnostima koje mogu utjecati na odabir škole i njihovu profesionalnu orijentaciju. Pri tome, institucionalni faktori u useljeničkom društvu, uz socijalno porijeklo učenika i individualne afinitete prema školi, igraju važnu ulogu.

\section{Obrazovanje u useljeničkom društvu - opći kontekst}

Obrazovanje i tržište rada prepoznati su kao područja od suštinske važnosti za strukturnu integraciju u useljeničkim društvima, ali mnogi smatraju da su to ujedno i slabe tačke tog procesa. Iz tog razloga, obrazovanje, skupa s poznavanjem njemačkog jezika, zauzima prvu poziciju od ukupno sedam područja akcije u Austriji koja su definirali eksperti u dokumentu naslovljenom kao "Nacionalni akcijski plan za integraciju“" (2012.)

(v. http://www.bmeia.gv.at/en/integration/national-action-plan/).

Zbog nepriznavanja ranije stečenih diploma u zemljama porijekla ili manjkavih jezičnih kompetencija, čime je ljudski kapital u većoj ili manjoj mjeri obezvrijeđen, visok procenat pripadnika prve generacije migranata nema baš pozitivno iskustvo, jer su angažirani u skladu s potrebama i mogućnostima tržišta rada. Njihova djeca, pak, nebitno jesu li rođena u Austriji ili su tamo došla u predškolskom uzrastu, trebalo bi da imaju veće šanse za karijerni uspjeh budući da su se tamo školovali i socijalizirali.

Papademetriou i sar. (2009) izdvajaju četiri faktora čijem utjecaju se u najvećoj mjeri može pripisati početna silazna socijalna mobilnost migranata: jezične barijere, razlike u obrazovnom postignuću, poteškoće 
koje se javljaju prilikom priznavanja istovrijednosti obrazovnih kvalifikacija stečenih u drugim zemljama (najčešće u zemlji porijekla) i problemima u pristupu mogućnostima putem socijalnih mreža i drugih kanala kojim se vrši "regrutacija". Mnogi od ovih problema mogu biti i prevaziđeni tokom vremena. (Papademetriou et al. 2009: 2).

Školski uspjeh djece iz doseljeničkih porodica ovisi o suptilnoj kombinaciji brojnih faktora koji djeluju na: mikronivou (individualne predispozicije, kognitivne sposobnosti, motivacija, jezična kompetencija, primarna socijalizacija, socijalni i ekonomski kapital porodice), mezonivou (neposredno okruženje kao što je susjedstvo, zatim vrtić, škola, izvanškolske aktivnosti unutar omladinskih, sportskih i drugih klubova, vršnjačke grupe itd.) i makronivou (kontekst prijema, školski sistem zemlje domaćina, mjere integracijske politike u toj oblasti itd.) (cf. Heckmann 2008; Esser 2006; Leseman 2007).

Navedeni faktori često djeluju združeno, tako da je nemoguće ustanoviti koji od njih ima dominatan utjecaj na obrazovno postignuće ove populacije.

U Zelenoj knjizi o obrazovanju djece migrantskog porijekla, ističe se da su nedostaci u obrazovanju koji se tiču djece migrantskog porijekla povezani s nekoliko faktora. Oni se primarno odnose na individualnu situaciju učenika kao što su:

- njihova društveno-ekonomska situacija;

- gubitak vrijednosti njihovog znanja ili nepriznavanje ranije stečene kvalifikacije;

- nedostatak znanja na jeziku zemlje domaćina;

- niska očekivanja porodice i zajednice;

- odsutnost uzora.

U odjeljku Doseljenici i obrazovanje - globalni pogled, autor Kelly polazeći od pitanja Kako prolaze učenici imigrantskog porijekla?, s namjerom da razluči mit od stvarnosti, poziva se na rezultate istraživanja programa PISA provedenog u 17 zemalja.

Naime, netačnim se pokazalo da:

- postoji veza između brojnosti doseljeničke zajednice i uspjeha učenika;

- učenici doseljenici ne žele učiti, odnosno da im manjka entuzijazam za školu;

- učenici doseljenici imaju slabe rezultate/postignuća u školi. 
S druge strane, u praksi su se potvrdile sljedeće teze:

- obrazovni problemi će postaviti znatne izazove u kasnijem traženju posla, odnosno tržišnom pozicioniranju;

- jezik objašnjava neke od obrazovnih problema doseljenika, ali ne sve;

- $\quad$ pružanje posebne jezične podrške je bitno (Kelly 2010).

Fokusiranost mjera integracijske politike na obrazovanje ima opravdan razlog jer se u dokumentu "OECD Reviews of Migration Education" navodi da "u odnosu na njihove vršnjake rođene u Austriji, učenici stranog porijekla imaju lošije rezultate na svim obrazovnim nivoima" (Nusche et al. 2009: 7).

Sumarno bi se mogle izdvojiti sljedeće glavne karakteristike obrasca školovanja migranata u Austriji, ali i u nekim drugim useljeničkim zemljama:

- Manja je vjerovatnoća da djeca iz neaustrijskih porodica predškolske dobi pođu u predškolsku ustanovu/vrtić, što je loš početak obrazovnog puta;

- Ispodprosječna postignuća u usporedbi s vršnjacima bez migrantske pozadine;

- Skloniji su pohađanju nižeg nivoa srednje škole, politehničke škole ili novih srednjih škola općeg obrazovanja;

- Učestao neuspjeh u prelasku s nižeg na viši nivo srednjoškolskog obrazovanja;

- Visoka stopa odustajanja kako od obaveznog tako i od sekundardnog obrazovanja.

(Heckmann 2008; Klaus and Liebeg 2009, Statistik Austria 2012)

Austrijski školski sistem podvrgnut je kritici nekih autora jer se "temelji na razvrstavanju i selektivnosti” (Nusche et al. 2009: 22), pri čemu nastavnici imaju iznenađujuće veliku autonomiju. Ispostavilo se da, kako to Bacher (2003) primjećuje, "nivo obrazovanja i profesionalni status roditelja imaju utjecaj na ishod prvog procesa selekcije koji se vrši na osnovu ocjena, roditeljskih preferencija i preporuka nastavnika" (prema Krause i Liebig 2011: 60). Stoga je u preporukama OECD-ovog izvještaja naglašena potreba povećanja "inkluzivnosti austrijskog sistema obrazovanja prevazilaženjem ranog razvrstavanja učenika i reduciranjem koncentracije imigrantskih učenika u najnižim nivoima srednjoškolskog obrazovanja" (Nusche et al. 2009: 8).

U ranijim radovima nekih teoretičara (v. npr. Douglas 1964; Bourdieu 1974; Boll, Bowe i Gewirtz 1994. u: Haralambos i Holborn 2002) zagovara 
se teza da su uloga roditelja i socijalno porijeklo također veoma utjecajne determinante obrazovnog toka pojedinca, što se može podvesti pod sintagmu "primarni učinak stratifikacije" (Boudon 1974 prema Haralambos i Holborn 2002). Takav nepovoljan splet okolnosti uobičajeno ne ide u prilog djeci iz migrantskih porodica.

Zbog socijalne izolacije i nevladanja lokalnim jezikom³, roditelji stranog porijekla mogu često upasti u "informativnu blokadu", čime su objektivno spriječeni da se bolje upoznaju sa svim mogućnostima školskog sistema u useljeničkom društvu (usp. Esser 2006). Zatvoreni krug interetničkih veza ili čak nepostojanje aktivnog društvenog života izvan porodice popraćen $\mathrm{s}$ relativno niskim nivoom obrazovanja i indiferentnošću, pa i ignorantskim odnosom, ozbiljno ugrožava obrazovno postignuće njihovih potomaka.

\section{Obrazovna slika bh. migranata u Austriji}

Uvid u obrazovni sastav i recentnu školsku statistiku bh. migranta $u$ Austriji bitno je izvršiti iz više razloga:

- "obrazovanje je ključni faktor u formiranju ljudskog kapitala" (Kelly 2010: 5);

- zato što otkriva minule obrasce migracija, odnosno razloge doseljavanja (posao, izbjeglištvo, studiranje, spajanje porodica itd.) (usp. Becker et al. 2009);

- to je jedan od markera/indikatora strukturne integracije migranata u useljeničko društvo;

- radi spoznaje jesu li i oni prezastupljeni u srednjim strukovnim školama;

- u kontekstu socijalnog porijekla djece bh. migranata i njihove "obrazovne sudbine" (Bourdieu i Passeron 1990) jer velik procenat njih je iz radničkih porodica;

- obrazovna postignuća/kvalifikacije određuju (budući) profesionalni status migranata i njihovih potomaka; $\mathrm{i}$

- zbog uloge koju obrazovanje ima u projektiranju alternativnih tendencija: uzlazna socijalna mobilnost ili socio-ekonomska reprodukcija (usp. Gidens 2006).

Broj migranata rođenih u Bosni i Hercegovini dobi od 15 i više godina prema školskoj spremi, na osnovu podataka iz registarskog popisa iz 2011. godine, iznosio je ukupno 149755. 
Nešto manje od polovine (45,3\%) osoba rođenih u BiH imalo je potpuno ili nepotpuno osnovno obrazovanje [ISCED $41 / 2$ ]. Zanat [ISCED 3B] je izučila trećina osoba bh. porijekla (32,1\%), dok je srednju strukovnu školu [ISCED 3B] završilo njih 7,5\%. Dakle, skoro $85 \%$ bh. migranata koncentrirano je u navedene tri obrazovne kategorije. Gimnazijsko obrazovanje (općeobrazovna viša škola) [ISCED 3A] steklo je 4,3\% osoba, a nešto viši procenat je onih koju su imali završenu višu strukovnu školu [ISCED 4A], tačnije 5\%. Izuzetno je nizak postotak bh. migranata s postsekundarnim i tercijarnim nivoom obrazovanja; manje od $1 \%$ njih posjedovalo je diplomu koledža [ISCED 5B] ili pedagoške visoke škole [ISCED 5A]. Samo 3,5\% migranata iz BiH imalo je visoku stručnu spremu u rangu nekog od fakulteta [ISCED 5A] (Statistik Austria, Registerzählung 2011).

Slična obrazovna struktura bila je i deset godina ranije kad je proveden popis stanovništva (2001), s tim da je udio osoba na najnižoj ljestvici obrazovne skale bio tad viši $(55 \%)$, i istovremeno niži procenat osoba $\mathrm{s}$ najvišim nivoom obrazovanja (2,2\%). Primjetno je da se ova struktura sporo mijenja, posebno u krajnostima obrazovne hijerarhije - prema udjelima osoba s najnižom i najvišom stručnom spremom. To je razumljivo jer se ovi podaci odnose isključivo na prvu generaciju migranata, pri čemu su izuzeta njihova djeca rođena na teritoriji Austrije (ili eventualno neke druge države).

Prikazana obrazovna slika osoba iz $\mathrm{BiH}$ odražava dominantne tipove i motive migracije (radne i humanitarne), njihovo socijalno porijeklo pa donekle i obrazovnu strukturu u matičnoj državi - BiH. Istraživanje pod naslovom "Iskustva doživljena tokom migracije i kulturološko prilagođavanje raseljenih osoba iz Bosne i Hercegovine koji trenutno žive u Beču“" provedeno 2000. godine na uzorku veličine 110 ispitanika u dobnom rasponu $21-72$ godine, sadržavalo je i pitanje školske spreme (Kučera i Lueger-Schuster 2000). Prema navedenom izvoru, više od dvije trećine osoba završilo je srednju školu (68,2 \%), dok je skoro petina (23,6 \%) ispitanika imala višu ili visoku stručnu spremu (fakultet). Ostatak od 8,2 \% završilo je osmogodišnje obrazovanje, što ukazuje na neusporedivo bolju obrazovnu strukturu od one ustanovljene popisom iz 2001. godine. To je i očekivano jer su u ranijim migracijskim valovima ekonomskog tipa uglavnom sudjelovale osobe s nižim obrazovanjem, odlazeći u Austriju i druge zemlje radi obavljanja neprestižnih poslova (usp. Mesić 2002). Neselektivna migracija izazvana ratom prisilila je mnoge ljude da napuste svoje domove i odu izvan domovine, bez mogućnosti izbora, tako da su jedan značajan udio izbjegličkog kontingenta činile i visoko obrazovane osobe. Drugo je pitanje da li su oni koji su ostali u Austriji uspjeli 
pronaći posao adekvatan nivou svog obrazovanja.

U cilju dobivanja potpunije obrazovne slike bh. migranata, potrebno je raspolagati i podacima gdje su se pripadnici prve generacije školovali: u Austriji, BiH ili kombinirano u obje zemlje, jer ta okolnost, osim što može signalizirati razlike u jezičnim sposobnostima, nerijetko objašnjava i postojanje nepremostivih prepreka prilikom pronalaska posla u struci. Dekvalifikacija je često povezana $s$ nepriznavanjem istovrijednosti nacionalnih i stranih diploma, što je u Nacionalnom akcijskom planu prepoznato kao jedan od problema. Komplicirana administrativna procedura verifikacije diploma stečenih u inostranstvu ${ }^{5}$ dodatno usložnjava situaciju u pogledu transfera ljudskog kapitala, doprinoseći time pojavi brain waste (traćenje pameti) ${ }^{6}$ (Emirhafizović 2013).

Autorica Herzog-Punzenberger (2003: 23) tvrdi da je „sudjelovanje u obrazovanju druge generacije važan faktor kako bi se situacija u društvu, potom i na tržištu rada kao i međugeneracijska društvena pokretljivost mogle shvatiti“.

Pri interpretiranju promatrane distribucije frekvencije učenika prema vrstama škola i shodno tome izvođenju određenih zaključaka, ne treba previdjeti činjenicu da je obrazovna politika Austrije usklađena s potrebama tržišta rada koje potražuje određene kvalifikacijske profile, iz čega proizlazi i kapacitiranost strukovnih (srednjih i viših) škola.

Slijedom uvodnih napomena o važnosti praćenja obrazovnog toka djece s migrantskom pozadinom, u nastavku će se dati pregled aktuelne distribucije učenika s bh. državljanstvom.

\section{Tabela 1.: Distribucija učenika s bh. državljanstvom prema vrstama škola u školskoj 2012./13. godini}

\begin{tabular}{|c|c|c|c|c|c|c|c|c|c|}
\hline \multirow[b]{2}{*}{ Ukupno } & \multicolumn{9}{|c|}{ Odabrane vrste škola } \\
\hline & $\begin{array}{c}\text { Niža } \\
\text { osnovna } \\
\text { škola }\end{array}$ & $\begin{array}{c}\text { Viša } \\
\text { osnovna } \\
\text { škola }\end{array}$ & $\begin{array}{l}\text { Nova } \\
\text { srednja } \\
\text { škola }\end{array}$ & $\begin{array}{c}\text { Specijalna } \\
\text { škola }\end{array}$ & $\begin{array}{l}\text { Politehnička } \\
\text { škola }\end{array}$ & $\begin{array}{c}\text { (AHS) } \\
\text { Općeobrazovna } \\
\text { viša škola } \\
\text { (gimnazija) }\end{array}$ & $\begin{array}{c}\text { Zanatska } \\
\text { škola }\end{array}$ & $\begin{array}{c}\text { (BMS) } \\
\text { Srednja } \\
\text { strukovna } \\
\text { škola }\end{array}$ & $\begin{array}{l}\text { (BHS) } \\
\text { Viša } \\
\text { stručna } \\
\text { škola }\end{array}$ \\
\hline 11659 & 3.228 & 1.673 & 1.673 & 175 & 358 & 1.239 & 1.223 & 738 & 1.551 \\
\hline
\end{tabular}

Izvor: Statistik Austria 2014.

Podaci iz Tabele 1. pokazuju raspodjelu učenika s bh. državljanstvom u školskoj 2012./13. godini u primarnom i sekundarnom stepenu obrazovanja. Fokusiramo li se na broj gimnazijalaca (1.239), koji posljednjih godina znatnije ne varira, s velikom vjerovatnoćom može se pretpostaviti da će oni nastaviti daljnje školovanje na univerzitetima, i time ostvariti svoje obrazovne 
ambicije. Mogućnost studiranja nije isključena ni za učenike strukovnih škola, ukoliko polože ispit zrelosti (maturu).

Dostupnost škola u većini slučajeva ne bi trebalo da bude problematična, ako se zna podatak da oko $60 \%$ bh. migranata živi u gradskom tipu naselja, što bitno određuje sadržaj i kvalitetu njihovog socijalnog života.

U zimskom semestru akademske 2012./2013., na javnim univerzitetima $u$ Austriji studirala su 2.632 državljana BiH (skoro 4\% svih redovnih studenata), od kojih 62\% (1628) s mjestom studiranja u Beču, a 27\% (708) u Gracu. Studenti iz BiH su četvrti po brojnosti stranih državljana, i ujedno prednjače u odnosu na studente iz pojedinih zemalja bivše Jugoslavije (Statistik Austria 2014).

Ekspanzija visokog obrazovanja među bh. migrantima stvara realne pretpostavke za socijalnu promociju koja je usko povezana s dobivanjem "profesionalnog državljanstva" (pojam: Standing 2009), odnosno boljim šansama za karijerno napredovanje po okončanju studija. $\mathrm{Na}$ osnovu predočenih podataka, izvjesna je optimistična prognoza da će se u doglednoj budućnosti desiti kvalitativna prekompozicija obrazovnog sastava uvjetovana porastom broja visokoobrazovanih osoba bh. porijekla, uz simultano smanjivanje udjela onih koji imaju niži stepen obrazovanja uslijed biološkog povlačenja starijih generacija.

\section{Zaključna razmatranja}

Prema svojoj obrazovnoj strukturi, bh. migranti u Austriji, promatrano u cjelini, pripadaju stranoj radnoj snazi s nižim nivoom obrazovanja. Međutim, to nikako ne znači da na zahtjevnom tržištu rada njihova znanja i vještine, stečene uglavnom u $\mathrm{BiH}$, nisu prepoznate $\mathrm{i}$ iskorištene. Heterogenost bh. migranata kao grupe može se promatrati po više osnova: socijalno porijeklo, različiti razlozi dolaska u Austriju, što se vidno reflektiralo i na njihov obrazovni sastav. Ranije radne migracije uglavnom su privlačile manje kvalificiranu radnu snagu, dok je među izbjeglicama, koje su u Austriju došle u prvoj polovini 1990-ih iz ratom zahvaćene BiH, bio znatan procenat $\mathrm{i}$ visoko obrazovanih osoba. Trend porasta broja studenata (porijeklom) iz BiH, ukoliko nakon završenog studija ostanu tamo živjeti, pruža realnu osnovu za skorije poboljšanje obrazovne strukture.

Kako je obrazovanje conditio sine qua non uzlazne društvene pokretljivosti, istraživačku pažnju u budućnosti trebalo bi usmjeriti na usporedbu nivoa obrazovanja, zanimanja i visine prihoda (primjenom npr. Duncanovog socioekonomskog indeksa - SEI), odnosno životni standard prve i druge 
generacije bh. migranata unutar iste porodice. Nalazi istraživanja jasno bi pokazali visinu korelacije između socijalnog statusa roditelja, koji su rođeni u $\mathrm{BiH}$, i obrazovnog postignuća njihove djece koja su se školovala i odrasla u drugačijem društvenom okruženju. Nadalje, detektirala bi se uloga institucionalnih faktora u određivanju toka obrazovanja i kasnijeg tržišnog ishoda, čime bi se, u konačnici, testirala uspješnost integracije u useljeničko društvo.

\section{HUMAN CAPITAL - EDUCATION - SOCIAL MOBILITY OUTSIDE THE HOMELAND IN THE CASE OF MIGRANTS FROM BOSNIA AND HERZEGOVINA AND THEIR DESCENDANTS IN AUSTRIA}

\section{- Abstract -}

This paper discusses the general context of education for children from migrant families in a different school system and social environment in relation to the country of origin of their parents, and then analyzes the educational structure of migrants from Bosnia and Herzegovina (BiH) in Austria. Due to the existence of the immigration flow with a long tradition between $\mathrm{BiH}$ and Austria, the country of destination has a special place on the map of BiH diaspora. Taking into account the result of external migration, and this is a direct loss of (pro)creative potential, the migration of the working age population is also an outflow of human capital (acquired knowledge, skills and abilities). The analysis shows that the educational structure of migrants from Bosnia and Herzegovina largely reflects the patterns and motives of immigration to Austria (labour migration, exile, studying, family reunification, etc.), as well as their social background. Family characteristics and the age structure of migrants in BiH require consideration to be given to the current distribution of their offspring by types of schools. It is an issue of particular interest because the education is, in addition to labour market, the main area of structural integration into a host society, such as Austria.

Keywords: human capital, educational structure, social mobility, host society, BiH migrants, Austria. 


\section{Literatura}

- $\quad$ Becker, T., Hockenos, P., \& Holmes, E. (2009). Remittances from Austria. Frankfurt School of Finance and Management. Vienna.

- Dostupno na: http://www.frankfurt-school.de/dms/ias/publications_2009/ remittances_austria/ Assessment $\% 20$ Study $\% 20-\% 20$ Remittances $\% 20$ from $\% 20$ Austria.pdf.

- Bourdieu, P. and Passeron, J-C. (1990) Reproduction in Education, Society and Culture. London, Newbury.

- $\quad$ Park, New Delhi: SAGE Publications.

- Emirhafizović, M. (2013). Demografske i socio-ekonomske karakteristike bosanskohercegovačkih migranta u Austriji. U: Emirhafizović, M., Ćosić. E., Osmić, Repovac-Pašić, V. (ur.) Migracije iz Bosne i Hercegovine.

- Sarajevo: Institut za društvena istraživanja, Fakultet političkih nauka Univerziteta u Sarajevu / Ministarstvo za ljudska prava i izbjeglice Bosne i Hercegovine (Sektor za iseljeništvo).

- $\quad$ Esser, H. (2006). Migration, Language and Integration. AKI Research Review No. 4. Berlin: Social Science Research Center.

- $\quad$ Gidens, E. (2006). Sociologija. Beograd: Ekonomski fakultet.

- Haralambos, M. i Holborn, M. (2002). Sociologija: teme i perspektive. Zagreb: Golden Marketing.

- Heckmann, F. (2008). Education and Migration: strategies for integrating migrant children in European schools and societies. Brussels: EuropeanCommission.

- Herzog-Punzenberger, B. (2003). Die 2. Generation an zweiter Stelle? Soziale Mobilität und etnische Segmentation in Österreich. Unveröff. Forschungsbericht an der Wiener Integrationsfonds, Wien.

- Huddleston, T. et al. (2011). Migrant Integration Policy Index (MIPEX). Brussels: Council and Migration Policy Group [Internet] Dostupno na: www.mipex.eu [pristupljeno 19. marta 2013.].

- Keely, B. (2010). Ljudski kapital: kako ono što znate oblikuje vaš život. Beograd: Ministarstvo prosvete Srbije i Zavod za udžbenike.

- $\quad$ Krause, K. and Liebig, T. (2011). Thelabour market integration of immigrants and their children in Austria. OECD Social, Employment and Migration Working Paper No. 127. Paris: OECD Publishing.

- Kučera, A. i Lueger-Schuster, B. (2000). Iskustva doživljena tokom migracije i kulturološko prilagođavanje raseljenih osoba iz Bosne i Hercegovine koje trenutno žive u Beču“. U: Duraković-Belko, E. i Powell, S. (ur.) Filozofski fakultet u Sarajevu, Psihosocijalne posljedice rata - rezultati empirijskih istraživanja provedenih na području bivše Jugoslavije. Sarajevo, BiH, 7. i 8. jul 2000. godine, Sarajevo: Filozofski fakultet u Sarajevu. Dostupno na: http://www.psih.org/2000b. pdf [pristupljeno 2. augusta 2014.].

- Leseman, P. (2007). Early education for immigrant children. The Transatlantic Task Force for Immigration and Integration. Migration Policy Institute.

- Dostupno na: http://www.migrationpolicy.org/pubs/LesemanEducation091907.pdf [pristupljeno 19. marta 2013].

- Mesić, M. (2002). Međunarodne migracije: tokovi i teorije. Zagreb: Zavod za sociologiju Filozofskog fakulteta. 
- Nusche, D., Shewbridge, C. i Rasmussen, C. L. (2009). OECD Reviews of Migrant Education: Austria. Paris: OECD. Dostupno na: http://www.oecd.org/ austria/44192225.pdf. [pristupljeno 2. augusta 2014.].

- Papademetriou, D. G., Sommerville, W. and Sumption, M. (2009). TheSocial Mobilty of Immigrants and Their Children. Washington, DC: Migration Institute Policy.

- Standing, G. (2009). Work After Globalisation: Building Occupational Citizenship. Cheltenham/ Northampton: Edward Elgar.

- Statistik Austria (2009). Arbeits- und Lebenssituation von Migrantinnen und Migranten in Österreich: Modul der Arbeitskräfteerhebung 2008. Wien: Statistik Austria. [Internet] Dostupno na: www.statistik.at [pristupljeno 19. jula 2012.].

- Statistik Austria (2014). Bildung in Zahlen. Wien: Statstik Austria. [Internet] Dostupno na: www.statistik.at [pristupljeno 1. oktobra 2014.].

- Statistik Austria (2012). Migration\&integration: figures.data.indicators 2012. Vienna: Statistik Austria.

- The World Bank (2011). Migration and Remittances. Factbook 2011 (2nd Edition). Washington DC: The World Bank.

\section{Internetski izvori}

http://europa.eu

www.statistik.at

http://www.bmeia.gv.at

\section{Bilješke}

1 Bosna i Hercegovina je, prema procjenama Svjetske banke, i na pragu druge decenije XXI stoljeća, izuzimajući Monaco, poslije Albanije, evropska zemlja s najvišim procentom iseljeničke populacije u odnosu na ukupan broj stanovnika. Isti izvor navodi da je 2000. godine $\mathrm{BiH}$ druga zemlja u Evropi po stopi emigracije visoko obrazovnih osoba sa udjelom od 23,9 \% (prvu poziciju iste godine zauzimala je Makedonija). Među njima je nemali broj univerzitetskih profesora i vrhunskih stručnjaka (ljekara, inženjera i drugih) iz različitih oblasti (World Bank, 2011). Intelektualni egzodus takvih razmjera zasigurno je izazvao velike poremećaje u normalnom funkcioniranju društvenih tokova, prijeteći da izazove kolaps sistema. Kad se ima u vidu da je, prema rezultatima popisa stanovništva provedenog uoči rata 1991. godine, udio osoba koje su stekle nivo tercijarnog obrazovanja iznosio manje od $4 \%$, onda su posljedice vanjske migracije 1990-ih godina drastične.

2 Austrija je između 1992. i 1995. godine prihvatila oko 90.000 izbjeglica iz Bosne i Hercegovine kojima je najprije dodijeljena privremena boravišna dozvola. Po završetku rata, otprilike se trećina njih vratila u svoju domovinu, dok se oko 60.000 osoba uspješno integriralo na tržište rada i ostalo živjeti u Austriji (Krause i Liebig, 2011).

3 Posebnu važnost uloge jezika u procesu strukturne integracije migranata naglašava autor Esser ,jer predstavlja i sredstvo svakodnevne komunikacije i resurs, posebno u kontekstu obrazovanja i tržišta rada“" (Esser, 2006). 
4 ISCED je akronim međunarodne standardne klasifikacije obrazovanja (engl. International Standard Classification of Education).

5 U publikaciji MIPEX (Migrant Integration Policy Index) navodi se da je uzrok tome komplicirani administrativni postupak priznavanja kvalifikacije stečene u inostranstvu, koji otežava pronalazak adekvatnog posla (Huddleston et al., 2011).

6 Prema rezultatima Anekte o radnoj snazi iz 2008. godine, naročito visok udio dekvalificiranih u radnom odnosu zabilježen je kod migranata/ica iz $\mathrm{BiH}(35,7$ \%), s tim da su žene više pogođene ovom negativnom pojavom (Statistik Austria, 2009). 